\title{
Drug-associated aquagenic wrinkling of the palms in an atopic male patient
}

\author{
Martin Glatz, ${ }^{1,2}$ Robert R Muellegger ${ }^{3}$
}

${ }^{1}$ Department of Dermatology, University Hospital of Zurich, Zurich, Switzerland

${ }^{2}$ National Institutes of Health, Bethesda, Maryland, USA ${ }^{3}$ Department of Dermatology, State Hospital Wiener Neustadt, Wiener Neustadt, Austria

\section{Correspondence to} Dr Martin Glatz, glatz.martin@gmx.net

Accepted 20 May 2014

\section{(1) CrossMark}

To cite: Glatz $\mathrm{M}$,

Muellegger RR. BMJ Case

Rep Published online:

[please include Day Month

Year] doi:10.1136/bcr-2014203929

\section{DESCRIPTION}

A 19-year-old male patient presented with a 2-week history of intensely pruritic white papules and mild wrinkling of the skin of both his palms (figure 1). Other body sites were unaffected. The skin lesions developed during showering and completely resolved by itself within 10-15 min afterwards. Before onset of symptoms, the patient started medication with paracetamol, ascorbic acid and clarithromycin because of an upper respiratory tract infection. His medical history was unremarkable except for mild atopic eczema, asthma and rhinoconjunctivitis with sensitisation to environmental allergens. Clinical findings and the unambiguous association to water contact were consistent with aquagenic wrinkling of the palms (AWP). AWP gradually disappeared within 10 weeks after discontinuation of drugs.

The epidemiology and pathogenesis of AWP remains unclear. Only a few cases are described,

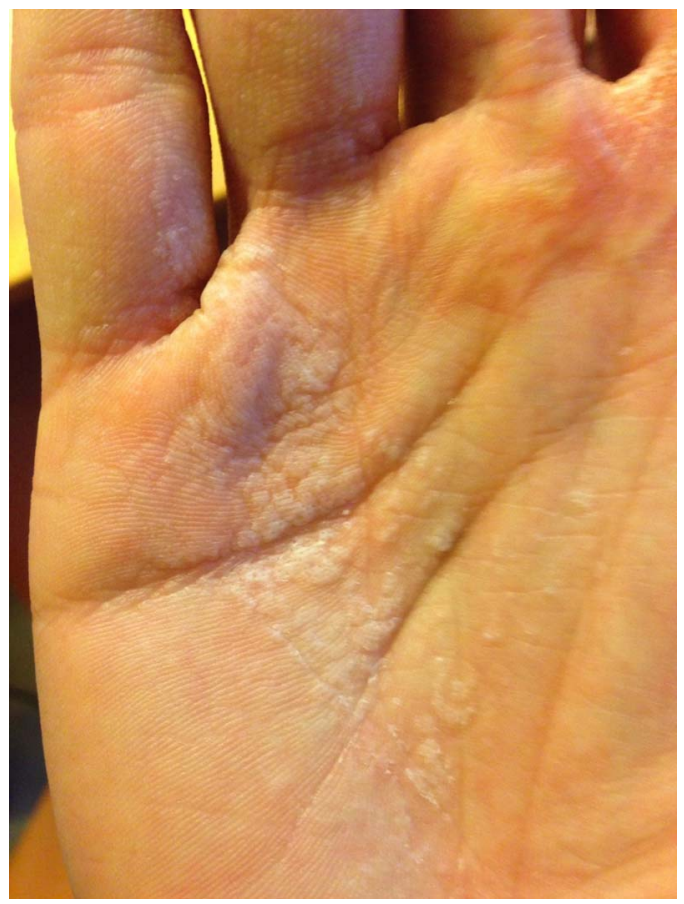

Figure 1 Right palm of the patient with white papules and mild wrinkling. usually in patients with cystic fibrosis. AWP supposedly is triggered by mutations in the cystic fibrosis transmembrane conductance regulator gene with production of hypertonic sweat and a subsequently increased water influx into eccrine gland ducts. ${ }^{1}$ However, AWP may occur in patients without clinical signs or history suggesting cystic fibrosis, as in our patient. In these patients, drugs such as aspirin or COX inhibitors may play a triggering role for AWP, supposedly due to drug-induced dysregulation of skin aquaporins. ${ }^{12}$ AWP in our patient was supposedly induced by an antipyretic and/or antibiotic medication. Paracetamol as a possible trigger for AWP has not been described, yet. The impaired skin barrier in the atopic patient might have served as the aggravating factor.

\section{Learning points}

- Aquagenic wrinkling of the palms is characterised by intensely pruritic white papules and mild wrinkling of the skin after water contact.

- It can be associated with the intake of drugs.

- Impaired skin barrier in atopy might serve as a triggering factor for the development of aquagenic wrinkling of the palms.

Contributors MG was involved in the medical care and in the diagnostic workup of the patient. He wrote the main part of the manuscript. RRM was responsible for the medical care of the patient at the initial visit and during follow-up and made the diagnosis. He critically reviewed the submitted manuscript version.

Competing interests None.

Patient consent Obtained.

Provenance and peer review Not commissioned; externally peer reviewed.

\section{REFERENCES}

1 Gunduz 0, Ozsarac KC, Ercin ME. Aquagenic palmar wrinkling induced by combined use of salazopyrin and indomethacin. Case Rep Dermatol 2013:5:21-6.

2 Khuu PT, Duncan KO, Kwan A, et al. Unilateral aquagenic wrinkling of the palms associated with aspirin intake. Arch Dermatol 2006;142:1661-2. 


\section{Images in...}

Copyright 2014 BMJ Publishing Group. All rights reserved. For permission to reuse any of this content visit http://group.bmj.com/group/rights-licensing/permissions.

BMJ Case Report Fellows may re-use this article for personal use and teaching without any further permission.

Become a Fellow of BMJ Case Reports today and you can:

- Submit as many cases as you like

- Enjoy fast sympathetic peer review and rapid publication of accepted articles

- Access all the published articles

- Re-use any of the published material for personal use and teaching without further permission

For information on Institutional Fellowships contact consortiasales@bmjgroup.com

Visit casereports.bmj.com for more articles like this and to become a Fellow 